DOI https://doi.org/10.30525/978-9934-26-038-4-35

\title{
ВИБІР ТА ДОЦІЛЬНІСТЬ ВИКОРИСТАННЯ ЗАСОБІВ ФІЗИЧНОЇ ТЕРАПІЇ ПРИ РЕАБІЛІТАЦІЇ ПАЦІЕНТІВ ІЗ СОМАТОФОРМНОЮ ДИСФУНКЦІЕЮ, ЗОКРЕМА БРУКСИЗМОМ
}

\author{
Саєнко О. В. \\ аспірант кафедри фізичної терапії, ерготерапії \\ Прикарпатський національний університет імені Василя Стефаника \\ м. Івано-Франківськ, Украӥна
}

У термінологічному словнику Американської академії орофасціального болю бруксизм визначається як «тотальна парафункціональна активність м'язів вдень і вночі, яка проявляється скреготінням, клацанням та стисканням зубів». Захворювання має наступні характеристики: проходить при відсутності суб'єктивної свідомості та не має ніякої фізіологічно обумовленої цілі; не підлягає контролю пропріоцептивної системи; проявляється несвідомим скороченням жувальних м'язів під час сну, при фізичному та розумовому навантаженні, у стресових ситуаціях; скорочення м'язів ізометричні, тривалі за часом та дуже інтенсивні.

Зважаючи на постійне зростання стресових ситуацій протягом останнього часу, зростає рівень тривожності, депресій та невротичних станів. Людина змушена швидко адаптуватися до змін. Прояви бруксизму більшість вчених вважає за адаптаційний механізм організму, що проявляється під час сну (нічний), та на протязі дня (денний). Згідно результатів досліджень у цій галузі, у $60-80 \%$ хворих на бруксизм виникають больові відчуття у ділянці жувальних м'язів та СНЩС.

Simons и Travell ще у 1980 році опублікували дані о найбільш вірогідні фактори, що сприяють виникненню порушення функції жувальних м'язів, в яких утворюються болісні ущільнення 3 ділянками гіперчутливості - м'язові тригерні точки. Автори означили два періоди - дисфункції та спазму м'язів, які беруть участь у жуванні. Основними причинами виникнення больового синдрому визначають психоемоційне порушення, що призводить до рефлекторного спазму жувальних м'язів.

М'язовий спазм, що виникає від надмірного розтягнення, скорочення та перевтоми м'язів $є$ основою розвитку больового синдрому. На первинному етапі у м'язах виникає залишкова напруга, потім ста- 
більний локальний гіпертонус. Він у свою чергу може стати причиною короткочасних больових спазмів. У інших випадках м'язовий тонус призводить до стабільного напруження. При тривалому фіксованому локальному гіпертонусі у м'язах виникають вторинні тканинні розлади (судинні, запальні, розлади обміну речовин). Локальні гіпертонуси можуть стати причиною локального та віддзеркаленого болю, що перетворюється у тригерні точки. Найчастіша зона ураження знаходиться у жувальних, скроневих, латеральній та медіальній крилоподібних м'язах.

Протягом останніх років бруксизм виключили із класифікації МКХ, як стоматологічну нозологію, та включили у складові соматоформних дисфункцій.

Вирішення проблеми бруксизму на сьогоднішній день залишається актуальною. Більшість досліджень підтверджують неможливість остаточного подолання хвороби, але лікування дозволяє досягнути тривалої ремісії.

Завдання нашої роботи, покращити якість життя пацієнтів, які страждають на бруксизм, ускладнений больовим синдромом. Отже доцільно розробити програму фізичної терапії з використанням засобів фізичної терапії, зокрема таких як кінезітерапія, масаж. 